\title{
KEDUDUKAN PEREMPUAN SEBAGAI SAKSI \\ DALAM ISLAM
}

\section{Thahir Maloko}

Fakultas Syariah dan Hukum

Email; m.thahirmaloko@gmail.com

\begin{abstract}
Abstrak
Islam adalah agama ketuhanan sekaligus agama kemanusiaan dan kemasyarakatan. Dalam pandangan Islam, manusia memupnyai dua kapasitas yaitu sebagai hamba Allah swt. dan sebagai representative Allah swt. (khalifah), tanpa membedakan jenis kelamin, etnis dan warna kulit. Kualitas keshalehan tidak hanya diperoleh melalui upaya penyucian melainkan juga kepedulian terhadap penderitaan orang lain. Islam menegaskan bahwa diskriminasi peran dan relasi gender adalah salah satu pelanggaran hak-asasi manusia yang harus dieliminir. Dengan demikian laki-laki dan perempuan memupnyai hak dan kewajiban yang sama dalam menjalankan peran sebagai hamba dan khalifah.
\end{abstract}

Kata Kunci: Perempuan; Saksi

\section{PENDAHULUAN}

Kehadiran Islam tidak lain kecuali untuk membebaskan manusia dari berbagai bentuk ketidakadilan. Apabila ada aturan yang dijadikan oleh masyarakat, tetapi aturan tersebut tidak sejalan dengan prinsip-prinsip keadilan, maka aturan itu harus ditolak. Demikian pula, apabila terjadi berbagai bentuk ketidakadilan terhadap perempuan dengan menggunakan dalil agama adalah sebuah alasan. Sebab, apabila ditelaah lebih jauh, sebenarnya tidak ada satu teks ayat al-Qur'an maupun hadis yang memberi peluang untuk memperlakukan perempuan secara semena-mena. Hubungan antara manusia dalam Islam didasarkan pada prinsip-prinsip kesetaraan, peraudaraan dan kemaslahatan.

Al-Qur'an mengakui adanya perbedaan antara laki-laki dan perempuan, tetapi perbedaan tersebut bukan perebedaan yang menguntungkan satu pihak dan merugikan pihak lainnya. Perbedaan tersebut di maksud untuk mendukung misi pokok al-Qur'an, yaitu terciptanya hubungan harmonis yang didasari rasa kasih saying di lingkungan keluarga. Hal tersebut merupakan cikal bakal terwujudnya komunitas ideal yang damai penuh ampunan Allah swt. Ini semua dapat terwujud manakala ada pola keseimbangan dan keserasian antara keduanya (laki-laki dan perempuan). ${ }^{1}$

${ }^{1}$ Lihat, Nasaruddin Umar, Argumen Kesetaraan Gender: Perspektif Al-Qur'an (Jakarta: Paramadina, 1999), h. 18-19 
Terhadap pengakuan tersebut, Islam menempatkan perempuan pada posisi yang sama dengan laki-laki. Kesamaan tersebut dapat dilihat dari tigas hal, pertama, dari hakekat kemanusiaan; Islam memberikan sejumlah hak kepada perempuan dalam rangka peningkatan kualitas kemanusiaannya, seperti hak kewarisan, hak persaksian. Kedua, Islam mengajarkan bahwa baik perempuan maupun laki-laki memperoleh pahala yang sama atas amal shaleh yang dikerjakan, dan memperoleh azab yang sama atas pelanggaran yang dikerjakannya, ketiga, Islam tidak mentolerir adanya perbedaan dan perlakukan yang tidak adil antara umat manusia.

Ketiga kesamaan tersebut, sejak awal Islam memproklamirkan agama pembebasan terhadap perempuan. Proklamir ini mengingatkan kepada kehidupan masyarakat arab yang dikenal sering membunuh anak perempuan, ternyata diserukan untuk melaksanakan aqiqah atas kelahiran anak perempuan, meskipun menyembelih seekor kambing. Selain itu masyarakat arab yang tidak mengenal konsep ahli waris dan saksi perempuan, ternyata diberi hak waris dan hak persaksian, meskipun dalam batas satu banding dua untuk laki-laki. Perempuan yang dimitoskan sebagai pelengkap keinginan laki-laki, ternyata diakui setara di depan Allah swt. dan mempunyai hak dan kewajiban yang sama sebagai penghuni surga (QS al-Baqarah/2:35). Perempuan (Hawa) sebagai penggoda laki-laki (Adam), ternyata dibersihkan namanya dengan keterangan bahwa yang terlibat dalam dosa kosmis adalah kedua-duanya (QS al-A'raf/7:20).

\section{PEMBAHASAN}

A. Peranan Perempuan Dalam Islam

Menguatnya gugatan tentang ketidakadilan terhadap perempuan dalam berbagai lapangan kehidupan, merupakan hasil dari gerakan kebangkitan perempuan di seluruh dunia dengan argumennya bahwa perempuan telah ditindas oleh sebuah tradisi yang mengutamakan laki-laki dan menganggap perempuan hanya sekedar makhluk kelas dua yang ditakdirkan untuk mengukuhkan tradisi tersebut.

Sesungguhnya Islam membawah ajaran yang diyakini mengangkat derajat dan martabat perempuan. Namun, ajaran yang luhur sering ditafsirkan secara dangkal, sehingga tidak jarang ditemukan penafsiran keagamaan yang justru merendahkan perempuan, seperti tuntunan mengenai keshalehan perempuan sering ditafsirkan dalam bentuk serba membatasi gerak dan aktivitas perempuan dalam masyarakat. Ibadah perempuan yang dianggap terbaik hanya dalam ruang lingkup rumah tangganya. Semakin banyak tinggal di rumah, dianggap semakin 
tinggi nilai ibadahnya. Selain itu, ketaatan seorang perempuan muslim kepada Allah swt. diukur dari ketaatannya kepada laki-laki atau suami. ${ }^{2}$

Memahami ungkapan tersebut, terlihat individualitas seorang perempuan diukur dari posisi sebagai pelengkap bagi laki-laki. Karenanya, menjadi tidak mungkin bagi perempuan untuk mengaktualisasikan dirinya, kecuali sebagai ibu dan istri yang baik dalam rumah tangganya, pada hal dalam berbagai aspek kehidupan, perempuan mempunyai berbagai profesi diantaranya disebutkan wanita karir, wanita pengusaha, wanita pedagang, menjadi Dewan Perwakilan Rakyat, Dosen, meskipun ada yang hanya tinggal di rumah tangganya mengurusi anak dan suaminya.

Berbagai aktivitas perempuan tersebut, terlihat jelas bahwa apapun namanya dan konsekwensinya, perempuan telah menduduki segala profesi dalam setiap bidang keilmuan, keterampilan. Apapun akibat dari kenyataan ini, tidak akan mampu mengembalikan perempuan untuk berdiam diri di rumah.

Sehubungan dengan berbagai profesi perempuan, sejarah telah mencatat pada masa awal kedatangan Islam ternyata perempuan telah banyak bekerja sebagai pedagang, penjaga pasar, penyamak kulit binatang. Perempuan bekerja karena dituntut oleh kebutuhan dalam kehidupan, sebagaimana terjadi pada Raithah, istri sahabat Rasulullah saw. yang bernama Abdullah Ibnu Mas'ud yang sangat aktif bekerja mencukupi kebutuhan hidup keluarga. Bahkan Al-Syifa' karena kepandiannya, sehingga ditugaskan oleh khalifah Umar bin Khattab sebagai petugas yang menangani pasar di kota Madinah. ${ }^{3}$

Memahami masalah peranan perempuan dalam Islam, maka di kemukakan bahwa Allah swt. menciptakan dua makhluk yang berbeda jenis yaitu laki-laki dan perempuan agar keduanya saling kenal dan mampu membangun kehidupan secara bersama-sama. Oleh karenanya, Islam memberikan jalan bagi perempuan pada setiap medan secara berdampingan dengan laki-laki. Perempuan menolong laki-laki sebagaimana laki-laki menolongnya. Perempuan menjadi sempurna bersama laki-laki sebagaimana laki-laki menjadi sempurna bersamanya. Islam tidak memisahkan antara keduanya. ${ }^{4}$ Hal ini tercermin dalam QS alTaubah/9:71

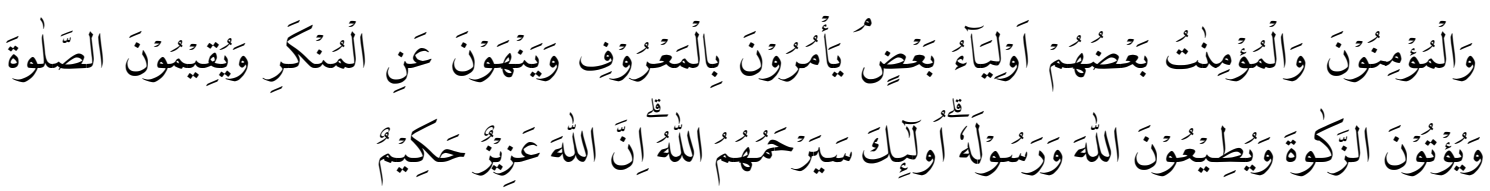

${ }^{2}$ Lihat Musda Mulia, Keadilan dan Kesetaraan Gender: Perspektif Islam (Cet. II; Jakarta: Lembaga Kajian Agama dan Gender, 2003), h. 85-86.

${ }^{3}$ Lihat M. Quraish Shihab, Membumikan Al-Qur'an : Fungsi dan Peran Wahyu dalam Kehidupan Masyarakat (Cet. XX; Bandung: Mizan, 1994), h. 275-276.

${ }^{4}$ Muhammad Abdul Qadir, Dunia Wanita dalam Islam (Cet. I; Jakarta: Lentera Basritama, 2000), h. 39. 
Terjemahnya:

Dan orang-orang yang beriman, lelaki dan perempuan, sebahagian mereka (adalah) menjadi penolong bagi sebahagian yang lain. Mereka menyuruh (mengerjakan) yang ma'ruf, mencegah dari yang munkar...5

Ayat tersebut memberikan pemahaman bahwa laki-laki dan perempuan merupakan mitra bersama dalam membangun kehidupan. Laki-laki dan perempuan keluar dari ruang lingkup kebapakan dan keibuan untuk berperan dalam esensi kemanusiaan untuk membangun kehidupan secara berdampingan. Islam memberikan jalan secara keseluruhan dihadapan perempuan dalam melaksanakan berbagai aktivitas kehidupan. Berdasarkan pemahaman tersebut, ditemukan peranan perempuan yang mampu mengekspresikan feminitasnya pada kehidupan rumah tangga, lingkungan keluarga maupun kepada sesame perempuan. Oleh karenanya peranan perempuan tetap merupakan peran penting dalam kehidupannya mempunyai potensi yang dinamis diberbagai aktivitasnya.

\section{B. Perempuan Sebagai Saksi dalam Islam}

Salah satu prinsip ajaran al-Qur'an adalah menyangkut persaksian perempuan yang sebelumnya tidak memiliki hak dan tidak diperhitungkan. Kehadiran Islam memperteguh dan mengakui keabsahan perempuan sebagai saksi melalui firman Allah swt. dalam QS al-Baqarah/2:282

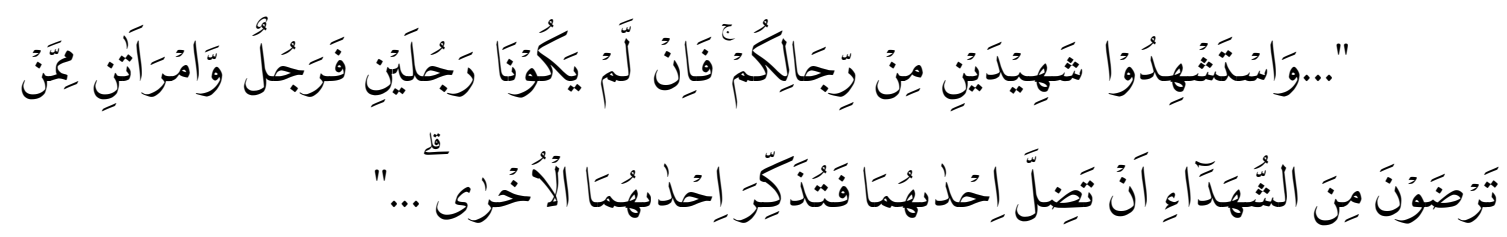

Terjemahnya:

...Dan persaksikanlah dengan dua orang saksi dari laki-laki (di antaramu). Jika tidak ada dua oang laki-laki, maka (boleh) seorang laki-laki dan dua orang perempuan dari saksi-saksi yang kamu ridhai, supaya jika seorang lupa, maka yang seorang mengingatkannya... ${ }^{6}$

Ayat tersebut harus dipahami dalam konteks asbabun Nuzul ayat yaitu untuk apa ayat tersebut diturunkan dan bagaimana situasi sosihistoris yang melingkup ketika ayat tersebut turun. Para ulama klasik pada umumnya cenderung memahami secara tekstual, dan kurang melakukan terobosan untuk menafsirkan secara kontekstual. 2012), h. 187.

${ }^{5}$ Kementerian Agama, RI., Alqur'an dan Terjemahnya (Cet. I; Bandung: Sya<mil Qur'an,

${ }^{6}$ Kementerian Agama, RI., Alqur'an dan Terjemahnya, h. 48. 
Aminah Wadud Muhsin, menjelaskan bahwa pemaknaan ayat tersebut sesungguhnya sangat sosiologis. Karena pada waktu itu, umumnya perempuan mudah dipaksa. Jika yang dihadirkan hanya seorang perempuan, maka perempuan akan menjadi sasaran ampuh bagi kaum laki-laki tertentu yang ingin memaksanya agar memberi kesaksian palsu. Tentu saja akan berbeda jika ada dua orang perempuan, mereka dapat saling mendukung, saling mengingatkan satu sama lain. Kesatuan tunggal yang terdiri dari dua orang perampuan dengan fungsi berbeda, tidak hanya menyebabkan individu perempuan menjadi berharga, tetapi dapat membentuk benteng kesatuan guna menghadapi saksi yang lain. ${ }^{7}$

Lebih lanjut Aminah mengatakan bahwa persaksian dua orang perempuan yang seakan disetarakan dengan satu laki-laki dalam ayat tersebut lebih disebabkan oleh adanya hambatan sosial pada waktu turunnya ayat, yaitu tidak adanya pengalaman bagi perempuan untuk masalah transaksi pada persoalan muamalah. Disamping itu seringkali terjadi pemaksaan terhadap perempuan, pada saat yang bersamaan sesungguhnya al-Qur'an tetap mengandung perempuan sebagai saksi yang potensial. ${ }^{8}$

Implikasi teoritis dari pemikiran tersebut adalah ketika kondisi zaman sudah berubah, perempuan telah mendapat kesempatan pengalaman yang cukup dalam persoalan transaksi atau muamalah, apalagi hal itu memang sudah menjadi profesinya, maka perempuan dapat menjadi saksi secara sebanding dengan lakilaki. Dengan demikian, persoalannya bukan pada jenis kelaminnya apakah laki-laki atau perempuan, melainkan pada kredibilitas dan kapibilitas ketika diserahi tugas untuk menjadi saksi.

Nashiruddin Bidan dalam Tafsir bi al-Ra'yi mengatakan bahwa kebolehan perempuan menjadi saksi sebagaimana ditegaskan dalam QS al-Baqarah/2:282 memperkokoh keyakinan kepada perempuan bahwa konsistensi Allah mengangkat derajat kaum perempuan sama dengan laki-laki, sehingga dalam transaksi yang mempunyai resiko yang besar sekalipun perempuan diikutsertakan sejajar dengan laki-laki yaitu sebagai saksi, ${ }^{9}$ tertolaklah anggapan bahwa perempuan itu lemah akal dan mempunyai sifat pelupa serta emosional.

Yunahar Ilyas membantah angapan terhadap perempuan mempunyai sifat pelupa dengan mengatakan bahwa tidak ada dasarnya perempuan memiliki sifat pelupa karena sifat pelupa adalah sifat manusiawi yang tidak hanya ada pada perempuan, melainkan juga ada pada laki-laki. Menyangkut sifat emosional perempuan yang sering diungkapkan, tetapi belum ada penelitian empiris yang mendukung asumsi spekulatif tersebut. ${ }^{10}$

Al-Sya'rawi dalam bukunya Al-Mar'ah fi Al-Qur'an yang dikutip Istibsyaroh mengeritik formula satu laki-laki dan dua perempuan mangatakan bahwa banyak kaum akademisi dan ilmuan memperbincangkan persaksian satu perempuan yang berhasil meraih gelas Magister atau Doktor dinilai sama dengan persaksian

\footnotetext{
${ }^{7}$ Lihat Aminah Wadud Muhsin, Qur'an and Woman. Diterjemahkan oleh Yazior Radianti dengan judul Wanita dalam Al-Qur'an (Cet. I; Bandung: Pustaka, 1992), 85.

${ }^{8}$ Lihat Aminah Wadud Muhsin, Qur'an and Woman. Diterjemahkan oleh Yazior Radianti dengan judul Wanita dalam Al-Qur'an, h. 85-86.

${ }^{9}$ Lihat Nashiruddin Baidan, Tafsir bi Ra'yi: Upaya Penggalian Konsep Wanita Dalam AlQur'an (Cet.I; Yogyakarta: Pustaka Pelajar, 1999), h. 69.

${ }^{10}$ Lihat Ynahar Ilyas, Feminisme dalam Kajian Tafsir Al-Qur'an Klasik dan Kontemporer (Cet. III; Yogyakarta: Pustaka Pelajar, 1998), h. 130.
} 
setengah satpam berkelamin laki-laki, kendati dia tidak dapat membaca dan menulis. Jangan ketidakadilan dalam persaksian ini sering dipersoalkan disetiap kesempatan, sedangkan mereka tidak memahami makna hokum yang disebutkan dalam al-Qur'an. ${ }^{11}$

Lebih lanjut beliau menafsirkan kata Syahadah dalam QS alBaqarah/2:282. Syahadah diambil dari Masyhad yaitu obyek yang terlihat jelas dengan kasat mata. Adapun Masyhad atau obyek tidak membutuhkan kepandian dan kecerdasan individu, tetapi lebih sangat memerlukan kesaksian mata telanjang dan lebih ditekankan kepada kejujuran. Berkaitan dengan itu, derajat hamba Allah swt. yang memperoleh gelar akademik dengan hamba yang tidak mampu membaca dan menulis adalah sama, sehingga dapat disimpulkan bahwa strata pendidikan seseorang tidak ada kaitannya dengan perihal kesaksian. Akhirnya kejujuran sangat urgen dalam kesaksian dan bukan kecerdasan akal. ${ }^{12}$

Menurut Asqhar Ali Engineer, sesuatu yang perlu diperhatikan bahwa dalam QS al_abaqarah/2:282 menunjukkan satu saksi laki-laki digantikan dengan dua saksi perempuan, hanya salah seorang diantara keduanya yang menjadi saksi, sedangkan yang satunya hanya berfungsi sebagai mengingatkan apabila ia ragu memberikan kesaksiannya, karena pada saat turunnya ayat tersebut selalu ada kemungkinan saksi perempuan melakukan kesalahan, bukan karena rendahnya kecerdasan, tetapi disebabkan kurang pengalaman masalah keuangan. ${ }^{13}$ Demikian juga Aminah Wadud mengatakan bahwa menurut susunan kata kedua perempuan dalam QS al-Baqarah/2:282 tidak disebut keduanya menjadi saksi karena satu perempuan ditunjukan untuk mengingatkan yang satu, dia bertindak sebagai teman kerjasama, meskipun dua orang perempuan, tetapi masing-masing berbeda fungsinya. ${ }^{14}$

Berdasarkan perspektif hermaneutika terhadap QS al-Baqarah/2:282 yang berbicara tentang saksi harus dilihat sebagai respons terhadap fakta sejarah pada saat ayat tersebut turun. Ketika fakta sejarah telah berubah, maka tidak tertutup kemungkinan untuk dilakukan reinterprestasi terhadap ayat tersebut dengan melihat secara komprehenship terhadap semua lingkar konsantris harmonisnya, yaitu hal-hal yang melatarbelakangi teks mapun hal-hal yang melatarbelakangi pembaca dan penafsir yang selalu terkait dengan waktu dan tempat tertentu. Dengan demikian, ayat tersebut harus dipandang secara kontekstual, bukan secara normative, karena ada tujuah ayat lainnya dalam al-Qur'an menyebutkan tentang kesaksian, dan tidak satu ayat yang menyebutkan saksi satu orang laki-laki digantikan dua orang perempuan. Ketujuah ayat yang dimaksud adalah :

Pertama, QS al-Maidah/5:106 berisi saksi tentang wasiat bagi orang yang akan mati hendaklah disaksikan oleh dua orang saksi, tidak dijelaskan jenis kelamin laki-laki atau perempuan, karena kalimat isnani dzawa 'adlin berarti dua orang saksi, keduanya boleh laki-laki dan keduanya boleh perempuan yang diharapkan adalah adil dan dapat dipercaya. Saksi masalah wasiat adalah

\footnotetext{
${ }^{11}$ Lihat Istibsyaroh, Hak-Hak Perempuan: Relasi Gender Menurut Tafsir Al-Sya'rawi (Cet. I; Jakarta: PT. Mizan Publika, 2004), h. 168.

${ }^{12}$ Lihat Istibsyaroh, Hak-Hak Perempuan: Relasi Gender Menurut Tafsir Al-Sya'rawi, h. 168.

${ }^{13}$ Lihat Asqhar Ali Engineer, Hak-Hak Perempuan dalam Islam (Cet. II; Yogyakarta: LSPA, 2000), h. 48.

${ }^{14}$ Lihat Aminah Wadud Muhsin, Qur'an and Woman. Diterjemahkan oleh Yazior Radianti dengan judul Wanita dalam Al-Qur'an, h. 86.
} 
kewajiban. Andai kata Allah swt. memandang rendah kepada perempuan, maka dijelaskan perempuan tidak dapat diberi tanggung jawab. Dengan demikian, dua orang saksi perempuan sebagai ganti satu orang saksi laki-laki terdapat dalam QS al-Baqarah/2:282 mempertimbangkan situasi dan kondisi serta konteks yang khusus, bukan karena inferioritas intelektual atau moral perempuan.

Kedua, QS al-Maidah/5:107 menerangkan kesaksian pada QS alMaidah/5:106 jika terbukti kedua saksi itu berbuat dosa, maka dua orang yang lain mengantikan kedudukannya. Dua orang saksi yang menggantikan juga tidak disebutkan jenis kelamin, melainkan dijelaskan bahwa haknya ahli waris menggantikan dua orang saksi diisyaratkan dengan sumpah.

Ketiga, QS al-Nisa/4:15 menerangkan tentang perbuatan keji harus disaksikan empat orang saksi; tidak disebutkan jenis kelamin. Ayat tersebut memakai kalimat 'alaihinna arbaatan minkum berarti laki-laki atau perempuan.

Keempat, QS al-Nur/24:4 menerangkan mereka yang menuduh perempuan berbuat keji harus disaksi empat orang saksi (tidak menyebutkan jenis kelamin laki-laki atau perempuan).

Kelima, QS al-Nur/24:6 menyebut mereka menuduh istrinya berbuat keji dan tidak mendapatkan empat orang saksi, maka sebagai gantinya adalah memakai sumpuh empat kali.

Keenam, QS al-Nur/24:8 menerangkan istri yang dituduh berbuat keji. Untuk menyatakan suami pembohong adalah memakai sumpah empat kali. Dengan demikian, seorang perempuan tidak hanya mempunyai hak untuk menjadi saksi, melainkan dapat membatalkan kesaksian laki-laki, karena sumpah dilakukan sebagai ganti saksi.

Ketujuh, QS al-Thalaq/65:2 menjelaskan tentang perempuan yang telah mendekati habis iddahnya apakah rujuk atau pisah diperintahkan untuk menggunakan dua orang saksi yang adil dengan menggunakan kalimat dzawai 'adlin minkum dan menegakkan kesaksian itu karena Allah swt. Dengan demikain, kata minkum tidak mewujudkan jenis kelamin (laki-laki atau perempuan).

\section{KESIMPULAN}

1. Sesungguhnya Islam membawa ajaran yang diyakini mengangkat derajat dan martabat perempuan, yaitu Islam memberikan sejumlah hak kepada perempuan dalam rangka meningkatkan kualitas kemanusiaan.

2. Al-Qur'an surat al-Baqarah/2:282 menunjukkan satu saksi laki-laki diganti dua saksi perempuan, hanya salah seorang diantara keduanya yang menjadi saksi, sedangkan yang satunya hanya berfungsi sebagai mengingatkan apabila ia lupa atau ragu.

3. Al-Qur'an surat al-Baqarah/2:282 tidak tertutup kemungkinan dilakukan reinterpretasi dengan melihat secara komprehenship hal-hal yang melatarbelakanginya. Ayat tersebut harus dipandang secara kontekstual, bukan secara normative, karena ada tujuh ayat (QS al-Maidah/5:106, 107, QS alNisa/4:15, QS al-Nur/24:4, 6 dan 8, QS al-Thalaq/65:2) yang menyebutkan kesaksian yang tidak ada satupun menyebutkan saksi satu orang laki-laki digantikan dua orang saksi perempuan dan tidak dijelaskan jenis kelamin. 


\section{DAFTAR PUSTAKA}

Al-Qur'an al-Karim.

Baidan, Nashiruddin. Tafsir bi Ra'yi: Upaya Penggalian Konsep Wanita Dalam AlQur'an. Cet.I; Yogyakarta: Pustaka Pelajar, 1999.

Engineer, Asqhar Ali. Hak-Hak Perempuan dalam Islam. Cet. II; Yogyakarta: LSPA, 2000.

Ilyas, Yunahar. Feminisme dalam Kajian Tafsir Al-Qur'an Klasik dan Kontemporer. Cet. III; Yogyakarta: Pustaka Pelajar, 1998.

Istibsyaroh. Hak-Hak Perempuan: Relasi Gender Menurut Tafsir Al-Sya'rawi. Cet. I; Jakarta: PT. Mizan Publika, 2004.

Kementerian Agama, RI., Alqur'an dan Terjemahnya. Cet. I; Bandung: Sya $<$ mil Qur'an, 2012.

Mulia, Musda. Keadilan dan Kesetaraan Gender: Perspektif Islam. Cet. II; Jakarta: Lembaga Kajian Agama dan Gender, 2003.

Muhsin, Aminah Wadud. Qur'an and Woman. Diterjemahkan oleh Yazior Radianti dengan judul Wanita dalam Al-Qur'an. Cet. I; Bandung: Pustaka, 1992.

Qadir, Muhammad Abdul. Dunia Wanita dalam Islam. Cet. I; Jakarta: Lentera Basritama, 2000.

Shihab, M. Quraish. Membumikan Al-Qur'an : Fungsi dan Peran Wahyu dalam Kehidupan Masyarakat. Cet. XX; Bandung: Mizan, 1994.

Umar, Nasaruddin. Argumen Kesetaraan Gender: Perspektif Al-Qur'an. Jakarta: Paramadina, 1999. 